\title{
PERCEPTIONS AND ATTITUDES OF VISITORS AT THE JARDÍN ZOOLÓGICO PAYO OBISPO AND THEIR INFLUENCE ON THE CONSERVATION OF NATIVE WILDLIFE
}

\section{PERCEPCIONES Y ACTITUDES DE LOS VISITANTES DEL JARDÍN ZOOLÓGICO PAYO OBISPO Y SU INFLUENCIA EN LA CONSERVACIÓN DE FAUNA SILVESTRE NATIVA}

\author{
Ángel Josué TZUC-SALINAS ${ }^{1}$, J. Rogelio CEDEÑO-VÁZQUEZ ${ }^{*}{ }^{*}$, FERNANDo GUAL-SILL ${ }^{2,4}$, Dolores \\ OFELIA MOLINA-ROSALES ${ }^{3}$
}

\begin{abstract}
${ }^{1}$ El Colegio de la Frontera Sur, Unidad Chetumal, Departamento de Sistemática y Ecología Acuática, Av. Centenario Km 5.5, 77014, Chetumal, Quintana Roo, México.<mvzangeltzuc@gmail.com>; <rogeliocedeno@gmail.com; rcedenov@ecosur.mx>

${ }^{2}$ Departamento de Producción Agrícola y Animal, Universidad Autónoma Metropolitana - Unidad Xochimilco, Calzada del Hueso No. 1100 Col. Villa Quietud, C.P. 04960, Cd. de México, México.<fguals@correo.xoc.uam.mx>

${ }^{3}$ El Colegio de la Frontera Sur, Unidad Campeche, Departamento de Ciencias de la Sustentabilidad, Av. Rancho Polígono 2A, Parque Industrial, 24500 Lerma-Campeche, Campeche, México. <dmolina@ecosur.mx>

${ }^{4}$ Facultad de Medicina Veterinaria y Zootecnia, UNAM, Circuito Exterior S/N, Coyoacán, Cd. Universitaria, C.P. 04510, Cd. de México, México.<f.gual.sill@gmail.com>

*Corresponding author: <rogeliocedeno@gmail.com; rcedenov@ecosur.mx>
\end{abstract}

Received: 17/02/2020; accepted: 30/09/2020; published online: 20/10/2020

Responsible editor: Sonia Gallina Tessaro

Tzuc-Salinas, A. J., Cedeño-Vázquez, J. R., Gual-Sill, F., Molina-Rosales, D. (2020) Perceptions and attitudes of visitors at the Jardín Zoológico Payo Obispo and their influence on the conservation of native wildlife. Acta Zoológica Mexicana (nueva serie), 36, 1-16. https://doi.org/10.21829/azm.2020.3612274

\begin{abstract}
This study focused on the relationship between the perceptions and attitudes of visitors at the Jardín Zoológico Payo Obispo and their support for the conservation of nine animal species, native of southeastern Mexico. Results from 198 surveys applied from November 2018 to February 2019, show that fear is the most important factor for visitors to decide if they support the protection of opossums and boas, while for ferruginous pygmy-owl and Morelet's crocodile it was the aesthetic consideration ("ugly"). For the remainder species, with the exception of the jicotea turtle, both, the fear, and the aesthetic perceptions directly influence conservation support.
\end{abstract}

Key words: fear; environmental education; wildlife protection; zoos; negative attitudes

Tzuc-Salinas, A. J., Cedeño-Vázquez, J. R., Gual-Sill, F., Molina-Rosales, D. (2020) Percepciones y actitudes de los visitantes del Jardín Zoológico Payo Obispo y su influencia en la conservación de fauna silvestre nativa. Acta Zoológica Mexicana (nueva serie), 36, 1-16. https://doi.org/10.21829/azm.2020.3612274

RESUMEN. Este estudio se enfocó en la relación entre las percepciones y actitudes de los visitantes del Jardín Zoológico Payo Obispo y el apoyo a la conservación de nueve especies de fauna, nativas del sureste de México. Los resultados de 198 encuestas aplicadas entre noviembre de 2018 y febrero de 2019 muestran 
que el miedo es el factor más importante para que los visitantes decidan si apoyan la protección de las zarigüeyas y las boas; mientras que para el búho pigmeo ferruginoso y el cocodrilo de Morelet este factor fue la consideración estética ("feo"). Para el resto de las especies, con excepción de la tortuga jicotea, tanto el miedo como la percepción estética influyen directamente en el apoyo a su conservación.

Palabras clave: miedo; educación ambiental; protección de fauna silvestre; zoológicos; actitudes negativas

\section{INTRODUCTION}

The loss of biodiversity is a multifactorial problem directly and indirectly related to human activities, such as the transformation of natural habitats, the introduction of species of commercial interest, or the illegal extraction of organisms from their natural environment (Kuussaari et al., 2009; Luna-Plascencia, CastañónBarrientos \& Raz-Guzmán, 2011; WWF/Dalberg, 2012). This has encouraged a conscious social concern about the impact of our actions and lifestyle on ecosystems; and it has also increased our interest in for understanding the motivations behind pro-environmental behaviors (Knight, 2008; Liordos et al., 2017).

Numerous studies suggest that aesthetic perception and attitudes toward wildlife, promote or discourage support for species conservation (Bjerke et al., 1998; Bjerke et al., 2001; Bjerke \& Østdahl, 2004; Røskaft et al., 2007; Knight, 2008; Schlegel \& Rupf, 2010; González et al., 2011; Liordos et al., 2017). For example, Martín-López et al. (2007) found that the affective factors towards a species were considered more important than scientific or ecological information. In this context, aesthetic animals, defined as those that have a physical appeal, enjoy a better conservation status than others and there is a possibility that the importance of supporting the conservation of the latter is made invisible by the conservation approach through charismatic flagship species (Brambilla et al., 2013).

On the other hand, attitudes are considered a construct originating from descriptive, inferential, and informative beliefs that predispose a subject to act or respond to other subjects, objects, or situations either positively or negatively (Ajzen \& Fishbein, 1980; Arnau \& Montané, 2010; Escalante-Gómez et al., 2012). In other words, attitudes motivate actions so that the subject feels safe or comfortable in front of another subject, regardless of whether the action is positive or negative for the recipient; for example, running away from an animal or deciding to kill it. One of the main exponents of these studies is Kellert (1985), who established that the most important negative attitude is fear, which has subsequently been the focus of several investigations (Bjerke et al., 1998; Bjerke et al., 2001; Knight, 2008; Liordos et al., 2017).

Environmental education is understood as a constructive process where the subjects interact with stimuli that allow them to make, reinforce, or discard ideas acquired during their previous life experiences in order to build a new way of relating with the natural environment (Lindemann-Matthies \& Kamer, 2006; Almeida \& García, 2009). Under this concept, environmental education is a tool that can influence or direct the attitudes and perception of people toward the natural environment and wildlife by promoting their intrinsic and ecological value. Among the different spaces where environmental education is developed, the zoo is a non-formal education space where people build and rebuild their knowledge and perceptions about the wildlife there exhibited, for example, through the routes they choose to follow and the information they decide to read. Since the visit is usually shared with family, friends, or groups of visitors, this individual knowledge can be collectively conformed (Cain \& Meritt, 2007).

Although zoos are non-formal education spaces, as environmental education is a fundamental part of their reason to be, there are doubts about the goals and results of zoos (Moss \& Esson, 2013). In Mexico, zoological parks and aquariums are governed by the General Wildlife Law, and can be registered as units of management for the conservation of wildlife (UMA by its acronym in Spanish) or facilities for wildlife management (PIMVS by its acronym in Spanish). Either way, an important aspect of their management plan 
is environmental education (DOF, 2000, Art 78 bis). In addition, the Mexican Norm 165 establishes the aspects that a zoo must take into consideration to obtain an accreditation; section 4.3 .7 of this norm indicates that zoos must provide sufficient budget, facilities and qualified staff in order to offer an adequate environmental education program (Secretaría de Economía, 2014).

The present study addressed the perception of visitors at the Jardín Zoológico Payo Obispo, located in Chetumal, Quintana Roo, Mexico, and how visitor perceptions can influence on their willingness to support the protection and conservation of nine target native species. This work is sustained by the theory of reasoned action (Ajzen \& Fishbein, 1980) which seeks to predict human behavior through their knowledge and attitudes. The study was designed according to a positivist approach, a common perspective in studies carried out in these institutions, and particularly in the study of attitudes and perceptions (Swanagan, 2000; Knight, 2008; DeGregoria et al., 2014; Jensen, 2014; Liordos et al., 2017; Moss et al., 2017), because it allowed us to do an exploratory study that did not require a long attention time from visitors. As other authors have pointed out, there is a lack of depth in the knowledge of the relationships found, which is acknowledged (Drury et al., 2011; Castillo et al., 2020).

\section{MATERIALS AND METHODS}

This study was carried out from November 2018 to February 2019, data were collected from surveys to visitors at the Jardín Zoológico Payo Obispo, all of who agreed to participate in the survey. Visitors were approached when arriving at the zoo's entrance; this area was chosen because it is a shaded resting site, it is the starting point for the tour, and respondents still do not know the information provided by the zoo. Respondents were 18 aged or older, regardless of whether they were alone, with partners, or in groups (family or otherwise).

The survey contained three sections. The first one was related to sociodemographic data like sex, age, education, place of origin, knowledge about protected species and pet ownership. The second section consisted of questions about aesthetic perceptions (if they considered a species "beautiful" or "ugly"), the existence of a negative attitudes (they were specifically asked whether species generate fear or safety), association with words that identified the species (pet, food, dangerous, harmful, medicinal, bad luck), and decisions related to conservation of those species under different hypothetic circumstances.

The target species, which occur in southeastern Mexico, were: white-fronted parrot (Amazona albifrons), cardinal (Cardinalis cardinalis), ferruginous pygmy-owl (Glaucidium brasilianum), jicotea turtle (Trachemys venusta), boa (Boa imperator), Morelet's crocodile (Crocodylus moreletii), white-nosed coati (Nasua narica), Virginia opossum (Didelphis virginiana), and Geoffroy's spider monkey (Ateles geoffroyi). In this section, pictures were used to facilitate the identification of species by respondents. These species were selected based on the most frequent ones received from 2009 to 2017 at the Wildlife Investigation and Conservation Centers of San Bartolomé Tekax and San Felipe Bacalar.

Finally, the third section included questions related to knowledge of the legal framework that regulates wildlife management and conservation in Mexico; their opinion about wildlife rehabilitation, and their willingness to donate in order to finance conservation, as well as their preferences about which species they would be willing to support their conservation through their donations.

The surveys were transcribed into an Excel spreadsheet for later analyses. The R software (R Core Team, 2018) was used to perform an association test on the sociodemographic data, as well as on the answers about perceptions and the free-word association of the nine species, through the chi-square test $\left(\chi^{2}\right)$ (Daniel, 1982). Finally, the R package vcd (Meyer et al., 2020) was used to determine the degree of association between the variables. 


\section{RESULTS}

We conducted 198 surveys, 101 to men and 97 to women. The majority of respondents (159) were from Quintana Roo (117 from Chetumal and 42 from other cities), while 31 came from other states within Mexico and the remainder eight came from other countries. Regarding the level of education of the respondents, nine had attained elementary school, 33 middle school, 77 high school, 65 college, four teacher-training studies, eight had a postgraduate degree, and two people did not specify their educational level. Respondents' age range was 18-75 years old, with an average of 34, and a median of 33 years old. According to collected data, 132 of the surveyed visitors had visited the zoo before, while for 65 it was their first time. The annual frequency with which those 132 people visit the zoo is variable, from 1 to 75 times a year (average 4.8, median 2). Of the total number of respondents, $84 \%$ had visited other zoos before, while $16 \%$ of visitors had only visited the Jardín Zoológico Payo Obispo.

The $\chi^{2}$ test only showed one statistically significant association between one sociodemographic data (level of education) and the conservation of species (knowledge about protected species), where a greater level of education had a moderate degree of association with the knowledge about protected species $\left(\chi^{2}=\right.$ $15.5, \mathrm{p}=0.04$, phi coefficient $=0.3$ ).

In addition, $22 \%$ of respondents had a wild animal at home as a pet. Parrots represented the group of species most commonly maintained in captivity (23\%), followed by fish (16\%), and turtles (10\%). It is worth mentioning that a third of the respondents who claimed having a wild animal as a pet also reported having more than one species.

Knowledge on protected species. When tested on their knowledge about protected species, most respondents mentioned one, followed by those who could not mention even one, and who mentioned two and three species; some mentioned four, and only three people mentioned five species (Fig. 1). When one to three species were mentioned, the majority were species with a natural distribution in Mexico; however, when four to five protected species were mentioned, the percentage of those with a natural distribution outside of Mexico (exotic) increased (Fig. 2). Species mentioned by respondents were mainly terrestrial mammals $(55 \%)$, followed by birds (20\%), reptiles $(12 \%)$, marine mammals $(11 \%)$, marine invertebrates $(0.7 \%)$, insects, fish, and amphibians (0.3\% each).

The diversity of mammals comprised 24 species and one general term (monkeys), of which 12 were exotic, and 13 were native to Mexico. Interestingly, 13 species were mentioned more than once, with jaguar in the first place (66 times); followed by tiger (18 times); white-tailed deer (11 times); lion (nine); tapir (six); giraffe, ocelot and panda (four each of them); Mexican grey wolf, monkeys, and Geoffroy's spider monkey (three each); and opossum and elephants with two mentions each.

Birds were the second most diverse group, with eight species and five general terms (macaws, parrots, birds, pheasants, and eagles). Toucans were often mentioned (10), but were surpassed by macaws (13), and tied with parrots (10). Other species were mentioned less often, like the golden eagle, peacock, and quetzal (three times each). Reptiles included four species and five general terms (crocodiles, iguanas, turtles, snakes, and sea turtles), Morelet's crocodiles were mentioned four times, but were surpassed by turtles (nine), sea turtles (five), and crocodiles (seven). Marine mammals comprised two species and two terms; the species most frequently mentioned was the manatee (22), followed by dolphins, whales, and vaquita porpoise (Phocoena sinus) with two mentions each one.

The second section was answered by 195 (98.5\%) participants. The least known species was the cardinal, followed by the white-nosed coati, which was frequently confused with the northern tamandua (Tamandua mexicana) and the raccoon (Procyon lotor). The Virginia opossum (Didelphis virginiana) was often confused with a mouse or a rat. Regarding the target species, a lack of knowledge of the animals had 
a small degree of association with fear in the case of the white-fronted parrot $\left(\chi^{2}=8.2, p=0.004\right.$, phi coefficient $=0.2)$ and the cardinal $\left(\chi^{2}=5.6, p=0.01\right.$, phi coefficient $\left.=0.2\right)$. In the case of Geoffroy's spider monkey, a lack of knowledge is positively related to transporting it to a zoo $\left(\chi^{2}=15.1, p=0.009\right.$, Cramer's $\mathrm{V}=0.2$ ). Only the lack of knowledge of the Virginia opossum was found to be associated with the decision of not supporting the conservation of this species $\left(\chi^{2}=10.4, p=0.001\right.$, phi coefficient $\left.=0.2\right)$.

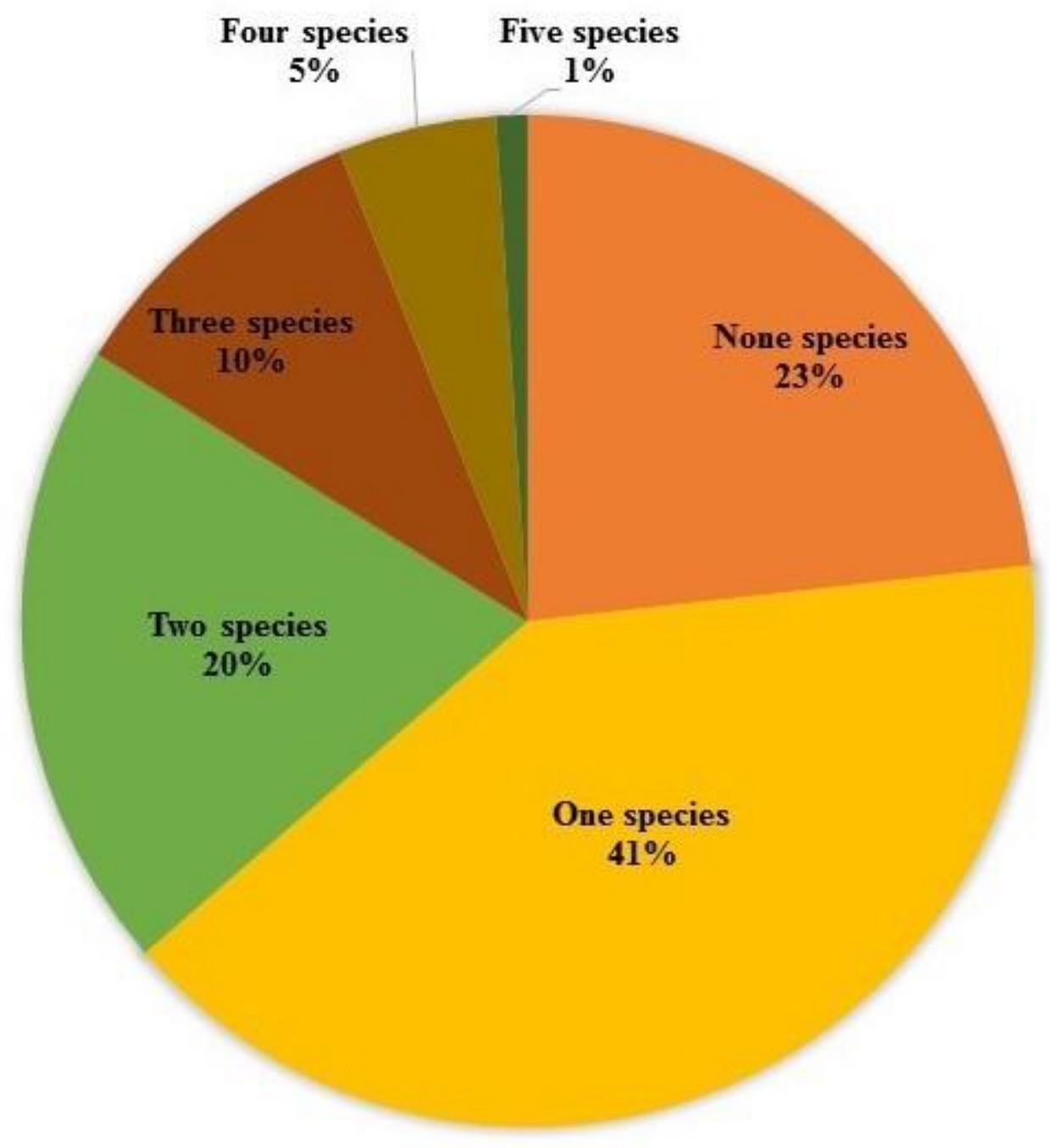

Figure 1. Percentage of respondents who mentioned from none to five protected species.

The respondents commonly had met white-fronted parrots, cardinals, ferruginous pygmy-owls, jicotea turtles, boas, and Virginia opossums in nature (in agricultural settings, flying over the city, or in the forest) and Morelet's crocodiles and Geoffroy's spider monkeys in the zoo. On the other hand, white-fronted parrots and jicotea turtles were known from the house of a relative, friend, or acquaintance, which was the second place where they were most frequently seen, with zoos in third place. These two species are also the most frequently seen as pets; however, there was no statistically significant correlation between the place where the species had been met, and them being perceived as potential pets. Species frequently considered "ugly" were the boa and the Morelet's crocodile, followed by the Virginia opossum; these species were also the ones that caused the most fear (Table 1). 
Species relation and uses. Most species, with the exception of Virginia opossum and boa, obtained similar scores regarding their relationship with the trade. The cardinal was the species with the greatest percentage (25\%) followed by Geoffroy's spider monkey (22\%), ferruginous pygmy-owl (15\%), jicotea turtle and white-fronted parrot (14\%), crocodiles (12\%), and white-nosed coati (11\%). Other uses given to wildlife are food and medicine. For the former, all species got lower scores: the species most frequently associated with food was the jicotea turtle $(15 \%)$, followed by the white-nosed coati (10\%), the Virginia opossum $(8 \%)$, and Morelet's crocodile $(6 \%)$. Only the boa was associated with a medicinal use. The species considered most dangerous were Morelet's crocodile (78\%) and boa (69\%), followed by Virginia opossum (14\%), white-nosed coati (10\%), and ferruginous pygmy-owl (11\%). However, when questioned about harmful species, Virginia opossum got the highest score (23\%) followed by white-nosed coati (6\%).

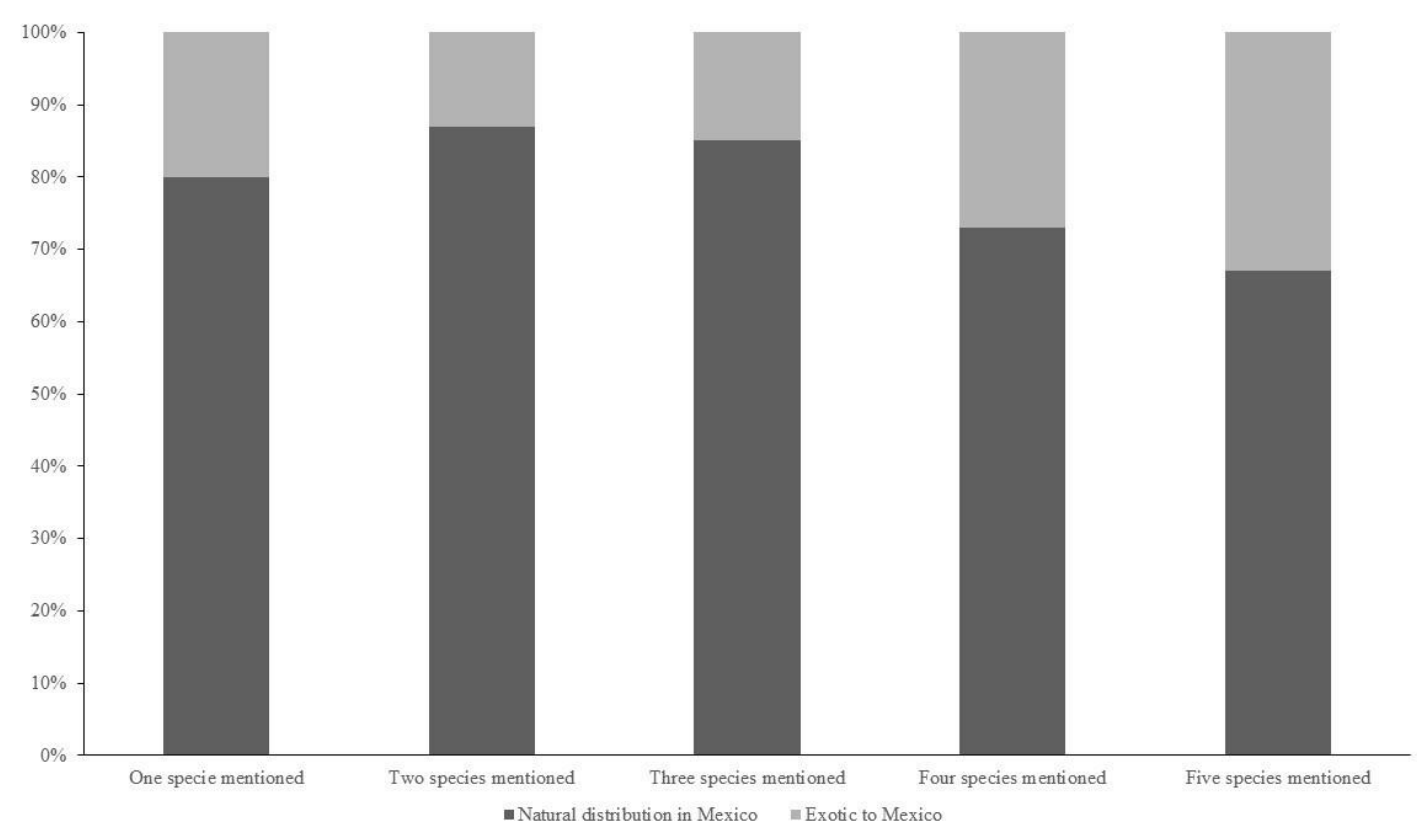

Figure 2. Percentage of species with natural distribution in Mexico and exotic to Mexico, in relation to the number of species mentioned.

Aesthetic and its effect on the perception and attitudes. The $\chi^{2}$ test showed a small to moderate degree of association between a negative aesthetic perception (a species being seen as "ugly") and the fear people exhibit towards target species of this study (A. albifrons $\chi^{2}=25.9, \mathrm{p}=3.4 \mathrm{e}^{-7}$, phi coefficient $=0.4 ; G$. brasilianum $\chi^{2}=15.4, \mathrm{p}=3.6 \mathrm{e}^{-5}$, phi coefficient $=0.3 ;$ T. venusta $\chi^{2}=32.3, \mathrm{p}=0.002$, phi coefficient $=0.4 ; B$. imperator $\chi^{2}=9.4, \mathrm{p}=0.002$, phi coefficient $=0.2 ;$ C. moreletii $\chi^{2}=13.8, \mathrm{p}=0.0001$, phi coefficient $=0.3 ; D$. virginiana $\chi^{2}=18.6, \mathrm{p}=1.5 \mathrm{e}^{-5}$, phi coefficient $=0.3 ; N$. narica $\chi^{2}=12.4, \mathrm{p}=0.0004$, phi coefficient $=0.2 ; A$. geoffroyi $\chi^{2}=36.7, \mathrm{p}=1.3 \mathrm{e}^{-9}$, phi coefficient $\left.=0.4\right)$, with the exception of the cardinal $(C$. cardinalis $)$. At the same time, this negative aesthetic perception was positively associated with "dangerous" in the case of ferruginous pygmy-owls $\left(\chi^{2}=12.6, p=0.02\right.$, Cramer's $\left.V=0.3\right)$, boas $\left(\chi^{2}=15.6, p=0.007\right.$, Cramer's $\left.V=0.3\right)$, crocodiles $\left(\chi^{2}=15.3, p=0.009\right.$, Cramer's $\left.V=0.3\right)$, white-nosed coatis $\left(\chi^{2}=19.5, p=0.003\right.$, Cramer's $\left.V=0.3\right)$ and Geoffroy's spider monkeys $\left(\chi^{2}=20.7, p=0.0004\right.$, Cramer's $\left.V=0.3\right)$. The same relation was obtained with the answer "kill it" when respondents were asked what they would do if they find an injured boa $\left(\chi^{2}=\right.$ 22.6, $p=0.003$, Cramer's V=0.3) or a Virginia opossum $\left(\chi^{2}=14, p=0.01\right.$, Cramer's $\left.V=03\right)$. 
Regarding a respondent's agreement with the protection of species, ferruginous pygmy-owls $\left(\chi^{2}=\right.$ $25.9, \mathrm{p}=3.5 \mathrm{e}^{-7}$, phi coefficient $\left.=0.4\right)$, boas $\left(\chi^{2}=5.9, \mathrm{p}=0.01\right.$, phi coefficient $\left.=0.2\right)$, Morelet's crocodiles $\left(\chi^{2}=\right.$ $6.3, p=0.01$, phi coefficient $=0.2)$, and Virginia opossums $\left(\chi^{2}=11.5, p=0.0008\right.$, phi coefficient $\left.=0.2\right)$ had a small degree of association between being described as "ugly" and respondents not supporting their protection. The same perception was associated with respondents not agreeing with these species being released once their health was re-established after treatment $\left(G\right.$. brasilianum $\chi^{2}=12.7, \mathrm{p}=0.0003$, phi coefficient $=0.2 ; B$. imperator $\chi^{2}=8.9, \mathrm{p}=0.002$, phi coefficient $=0.2 ;$ C. moreletii $\chi^{2}=4.5, \mathrm{p}=0.03$, phi coefficient $=0.2 ; D$. virginiana $\chi^{2}=4.8, \mathrm{p}=0.02$, phi coefficient $\left.=0.2\right)$. The aesthetic perception on boas $(B$. imperator) was related to the sex of the respondents: men were more likely to describe this species as "beautiful", while women qualified it as "ugly" $\left(\chi^{2}=7.4, p=0.006\right.$, phi coefficient $\left.=0.2\right)$.

Table 1. Percentage of knowledge, place of meeting, aesthetic perception, attitude, and relations of words to the nine target species.

\begin{tabular}{lccccc}
\hline \multicolumn{1}{c}{ Species } & Knowledge & $\begin{array}{c}\text { Place of } \\
\text { meeting }\end{array}$ & $\begin{array}{c}\text { Aesthetic } \\
\text { (appeal) }\end{array}$ & $\begin{array}{c}\text { Attitude } \\
\text { (safety) }\end{array}$ & $\begin{array}{c}\text { Relations of } \\
\text { words }\end{array}$ \\
\hline Amazona albifrons & $96 \%$ & $\begin{array}{c}42 \% \text { Nature } \\
34 \% \text { House }\end{array}$ & $98 \%$ & $92 \%$ & $\begin{array}{c}81 \% \text { Pet } \\
14 \% \text { Commercial }\end{array}$ \\
\hline Cardinalis cardinalis & $75 \%$ & $\begin{array}{c}46 \% \text { Nature } \\
18 \% \text { Zoo }\end{array}$ & $99 \%$ & $97 \%$ & $\begin{array}{c}62 \% \text { Pet } \\
15 \% \text { Commercial }\end{array}$ \\
\hline $\begin{array}{l}\text { Glaucidium } \\
\text { brasilianum }\end{array}$ & $95 \%$ & $\begin{array}{c}54 \% \text { Nature } \\
22 \% \text { Zoo }\end{array}$ & $92 \%$ & $79 \%$ & $\begin{array}{c}33 \% \text { Pet } \\
25 \% \text { Bad luck }\end{array}$ \\
\hline Trachemys venusta & $99 \%$ & $\begin{array}{c}44 \% \text { Nature } \\
32 \% \text { House }\end{array}$ & $95 \%$ & $91 \%$ & $\begin{array}{c}78 \% \text { Pet } \\
15 \% \text { Food }\end{array}$ \\
\hline Boa imperator & $98 \%$ & $\begin{array}{c}44 \% \text { Nature } \\
39 \% \text { Zoo }\end{array}$ & $18 \%$ & $56 \%$ & $69 \%$ Dangerous \\
$16 \%$ Pet
\end{tabular}

Fear, perception, and support for conservation. The responses of men were mostly associated, in a small degree, with security in the case of white-fronted parrots $\left(\chi^{2}=7.9, p=0.004\right.$, phi coefficient $\left.=0.2\right)$, cardinals $\left(\chi^{2}=6.3, p=0.01\right.$, phi coefficient $\left.=0.2\right)$, ferruginous pygmy-owls $\left(\chi^{2}=15.8, p=6.9 \mathrm{e}^{-5}\right.$, phi coefficient $\left.=0.3\right)$, and jicotea turtles $\left(\chi^{2}=4.1, p=0.04\right.$, phi coefficient $\left.=0.1\right)$, while the women's responses were associated with fear towards these species. No association could be found between the sex of the respondents and their fear towards the other species (boa, Morelet's crocodile, white-nosed coati, Virginia opossum, and Geoffroy's spider monkey). Fear had a moderate degree of association with "dangerous" in the cases of boas $\left(\chi^{2}=22.1, p=0.0004\right.$, Cramer's $\left.V=0.4\right)$, Morelet's crocodiles $\left(\chi^{2}=18.4, p=0.002\right.$, Cramer's $\left.V=0.3\right)$, Virginia opossums $\left(\chi^{2}=19.3, \mathrm{p}=0.003\right.$, Cramer's $\left.V=0.4\right)$, white-nosed coatis $\left(\chi^{2}=15.4, \mathrm{p}=0.01\right.$, Cramer's $\mathrm{V}=0.3)$, and Geoffroy's spider monkeys $\left(\chi^{2}=17.8, \mathrm{p}=0.001\right.$, Cramer's $\left.\mathrm{V}=0.3\right)$. Only in the case of Virginia opossums, fear had a small degree of association with the action of ignoring this species in the case of finding an injured individual $\left(\chi^{2}=13.5, \mathrm{p}=0.01\right.$, Cramer's $\left.\mathrm{V}=0.2\right)$, as well as the decision not to support their conservation $\left(\chi^{2}=9.1, \mathrm{p}=0.002\right.$, phi coefficient $\left.=0.2\right)$ or their release $\left(\chi^{2}=4, \mathrm{p}=0.04\right.$, phi coefficient $=$ 
0.1 ). This association between fear and opposition to the release of a species was also found for the ferruginous pygmy-owl $\left(\chi^{2}=3.7, p=0.05\right.$, phi coefficient $\left.=0.1\right)$.

An interesting result was the significant association between the frequency with which respondents visit the Payo Obispo Zoo and the sense of security in relation to boas and Morelet's crocodiles, the two species which most respondents perceived as unsafe $\left(\chi^{2}=28.9, p=0.003\right.$, Cramer's $V=0.5$, and $\chi^{2}=24.3, p=$ 0.01 , Cramer's $V=0.4$, respectively). However, no statistically significant association was found between not having previously visited the zoo and a sense of security or fear towards any of the nine focal species of this study.

When respondents were asked if rehabilitation (understood as the act of treating injured wild animals) helps towards the conservation of these species, $98 \%$ agreed and $91 \%$ considered that through this activity they can learn some of the threats facing wildlife.

Regarding knowledge of the legal framework of wildlife protection, $67 \%$ of respondents stated that a law that protects wildlife species exists, $31 \%$ did not know about such law, and the remainder (2\%) did not answer. Of those who claimed to know the law, $73 \%$ could not recall its name, $8 \%$ mentioned SEMARNAT (Secretariat of Environment and Natural Resources), 2\% mentioned PROFEPA (Federal Attorney for Environmental Protection), 5\% said the law's name was Law of Environmental Protection; in the same percentage, Law of Animal Protection, while only two respondents mentioned the correct name of the General Wildlife Law. Another important aspect is the limited presence of the environmental authorities in the answers of the respondents: while the majority of the respondents declared that they would call someone to help them if they encountered a wildlife-related problem (65/198), 46\% of these people did not know which authority to call, seven respondents said that they would call a veterinarian, six more would call the civilian protection authorities, five would call firefighters, and only three people would call PROFEPA.

Finally, one of the general behaviors seen between the respondents was their willingness to donate money for the conservation of some species: 69\% claimed they had made some donation before, and 90\% said they were willing to make it. Once again, respondents were more likely to have the intention of donating to conservation of terrestrial mammals, followed by birds, while marine mammals, reptiles, and marine invertebrates were less favored (Fig. 3); in this section no fish, amphibians, or insects were mentioned. The species whose conservation respondents most frequently had the intention of donating to were, in the case of mammals, the jaguar, followed by the Geoffroy's spider monkey, and the white-tailed deer (Table 2); for birds, parrots occupied the first place, followed by other birds, and macaws (Table 2); the marine mammals that would receive the most donations were the manatee, followed by whales and dolphins (Table 2); regarding reptiles, sea turtles and other turtles were the most frequently mentioned, followed by iguanas and crocodiles (Table 2). Regarding the allocation of their donation, 53\% of respondents said they would like their donation to be invested for the conservation of the species' habitats, $15 \%$ in the creation of facilities to maintain and reproduce them, and $12 \%$ in wildlife rehabilitation programs.

Table 2. Species most frequently mentioned to receive donation by the respondents.

\begin{tabular}{cccccccc}
\hline Terrestrial mammals & No. & Birds & No. & Marine mammals & No. & Reptiles & No. \\
\hline Jaguar & 32 & Parrots & 29 & Manatee & 10 & Sea turtles & 3 \\
Geoffroy’s spider monkey & 11 & Birds & 12 & Whales & 2 & Turtles & 3 \\
White-tailed deer & 6 & Macaws & 9 & Dolphins & 2 & Iguanas & 2 \\
& & & & & & Crocodiles & 2 \\
\hline
\end{tabular}




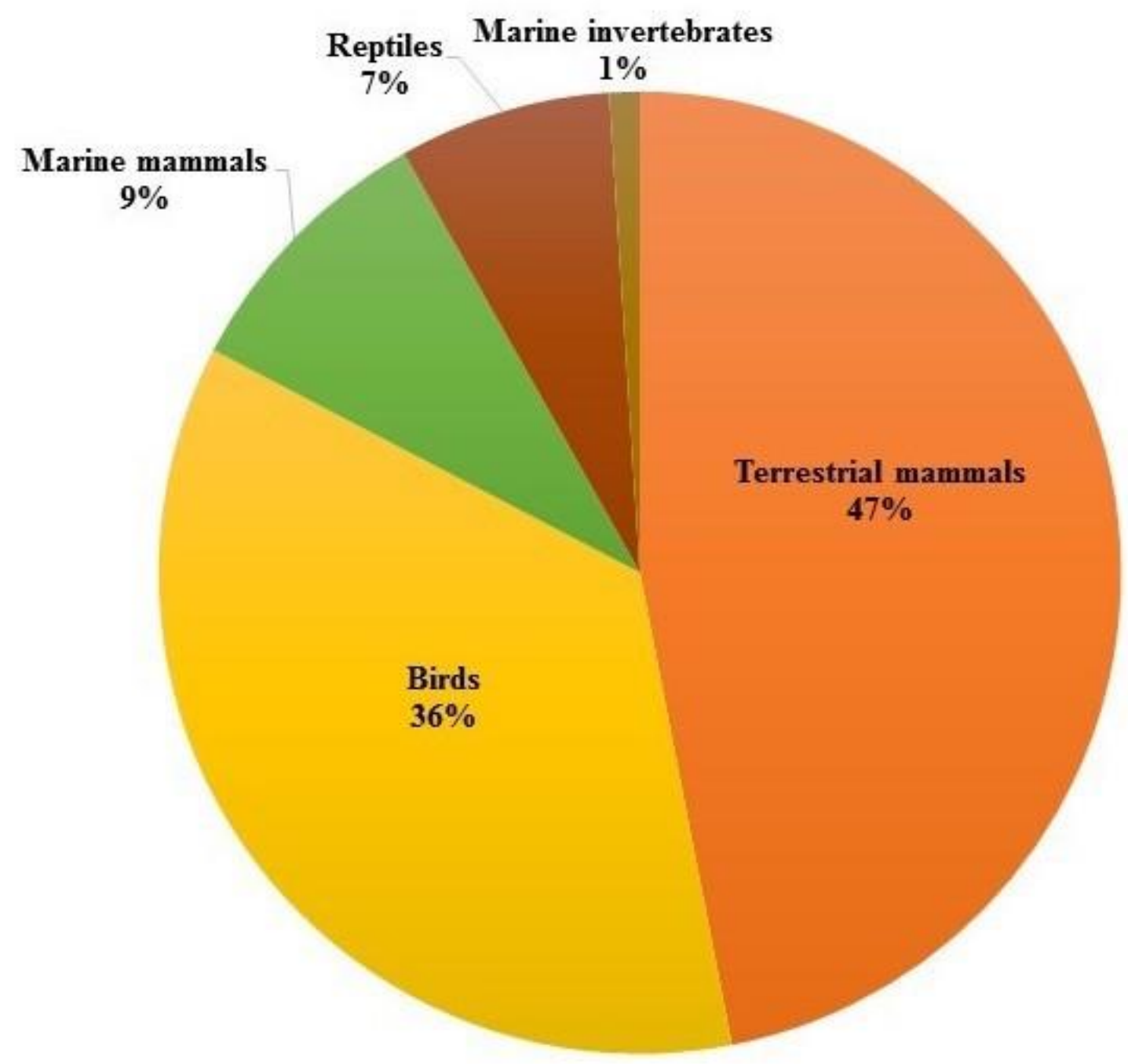

Figure 3. Percentage of donation intention by the respondents per animal group.

\section{DISCUSSION}

During the survey we did not see any cardinals in the zoo's facilities. Nevertheless, we found eight of the nine focal species. This allowed us to establish an initial panorama of the knowledge, attitudes, and perceptions on these species. Our results show, which species require special attention, and can help in designing environmental education programs, as well as establishing a frame of reference for research in this and other zoological institutions.

In this study, the knowledge of zoo visitors about wildlife was mostly associated with native species (80\%), contrary to what was observed in other studies (González et al., 2011). This may be due to the strong presence of charismatic species like jaguar, tapir, manatee, and parrots, which are priority species for conservation. Felines (jaguar and ocelot) and an ungulate (tapir) have been the most frequently mentioned species, in contrast to spider monkeys, snakes, and iguanas identified by respondents in a similar survey in Venezuela (González et al., 2011). As for the most frequently mentioned exotic species, our results agree with those reported by Gonzalez et al. (2011), with the tiger being the most frequent, followed by the lion. 
The species frequently seen as pet animals (white-fronted parrot, jicotea turtle, spider monkey and cardinal) also have been recognized as such in previous studies, mainly in rural communities (QuijanoHernández \& Calmé, 2002; Chablé-Santos \& Delfín-González, 2010; Segovia-Castillo et al., 2010; González-Bocanegra et al., 2011; Puc-Gil \& Ratana-Guiascón, 2012; Buenrostro-Silva et al., 2016; Ramírez-Mella et al., 2016), and a few among urban dwellers (Drews, 2001; Duarte-Quiroga \& Estrada, 2003; González et al., 2011). The study site is located in Chetumal City, which is a small and expanding urban area influenced by people from nearby rural settlements, which may be the reason for a higher prevalence of respondents who own wild species as pets compared to those reported by Drew (2001), but lower than the reported by González et al. (2011).

With the exception of Virginia opossum and boa, target species were identified as species of commercial, food, or medicinal value, results which agree with those of others authors (Quijano-Hernández \& Calmé, 2002; Méndez-Cabrera \& Montiel, 2007; Chablé-Santos \& Delfín-González, 2010; GonzálezBocanegra et al., 2011; Puc-Gil \& Ratana-Guiascón, 2012; Buenrostro-Silva et al., 2016; Ramírez-Mella et al., 2016). Most studies on wildlife use or hunting have been conducted in rural communities unlike this study site; however, the close relationship between Chetumal City and rural communities may influence the different uses and perceptions on the target species, despite the relationship with wildlife being different. For example, in rural community studies, Virginia opossum and white-nosed coati were considered the most harmful species, and both have been identified as the most hunted species due to damage to crops or minor poultry (mainly birds) (Quijano-Hernández \& Calmé, 2002; Chablé-Santos \& Delfín-González, 2010; Segovia-Castillo et al., 2010; Buenrostro-Silva et al., 2016). In the urban zones, the Virginia opossum is a species that can be frequently seen and is strongly associated with garbage, which causes it to be perceived as a harmful species. On the other hand, in this study, respondents saw the white-nosed coati as a companion animal with commercial value. This could be due to common encounters with these animals in hotels and tourist areas, where troops (adults, juveniles and young) often approach visitors in search food.

Our findings suggest that aesthetic perceptions and negative attitudes play an important role in supporting species conservation, similar to results found in other studies (Knight, 2008; Liordos et al., 2017). In a study carried out with students of a southern university in the United States (Knight 2008), nine species in danger of extinction that are protected by United States law were selected and presented through 10 photographs, one of which showed a cub and an adult cougar (Puma concolor). The results of that work suggest that aesthetic perception has a great influence on the decision of whether to support a species' conservation, since the species seen as "ugly" (Ozark big-eared bat, Dolloff cave spider, two-striped garter snake) obtained little support. These species also caused some fear among the respondents. Similar results were obtained by Liordos et al. (2017) with inhabitants of Northern Greece, where 12 species included in the Red Book of Greece were selected; once again, the aesthetic appreciation and safety or fear sensation were important elements in deciding whether to support species' conservation. In that work, the Milos viper, the Cretan tube web spider, and the western barbastelle obtained the least support, and were the least attractive animals and the ones that caused the most fear; in addition, the fire-bellied toad and the great white shark were selected too.

Fear constitutes one of the most important factors involved in the actions of people towards the species addressed in this study. For this reason, the conceptualization and analysis of this factor are important. Fear has been proposed as the emotional state of a person caused by specific stimuli related to a threat themselves, and this triggers behaviors that restore their state of safety (Öhman \& Mineka, 2001; Adolphs, 2013). In this sense, Gordillo-León et al. (2015) propose the conceptualization of physical fear as the fear of feeling painful sensations arising from a real or imaginary external stimulus. Various works have categorized fear, according to the stimulus that originates it, and although there is no consensus on the number of categories, the fear towards animals is a constant in all studies (Scherer \& Nakamura, 1968; Gullone \& King, 1992; Taylor, 1998; Gullone, 2000). The animals addressed in the aforementioned studies were snakes, lizards, spiders, bears, bees, bats, rats, dogs, cats, and others. Some studies suggest that fear 
can be innate, acquired, and / or culturally shared; for example, fear towards snakes taught in Christian cultures due to them being seen as a demonic representation (González-Martínez, 1990). However, González-Martínez (1990) also states that, in general terms, the fear of people towards animals develops between two to three years of age.

In a study involving people 18 to 65 years old in Mexico City, Caraveo-Anduaga and Colmenares (2000) found that $65.6 \%$ of the interviewed had some specific phobic symptoms towards animals, with snakes and rats being the most frequently feared. In Toluca City, Valdez-Medina et al. (2010) conducted a study to learn about the past, present, and future fears of one population of children (average 11 years old), adolescents (average 15 years old), and adults (average 45 years old), in which they found that fear towards animals is a constant for children in their past, present, and future; however, its prevalence decreased in adolescents and was limited to their past and present, and in the case of adults, fear towards animals was only present in their past. Despite the above-mentioned study, in this work we found a significant prevalence of present fear in adults towards species such as boa, Morelet's crocodile, and Virginia opossum.

As pointed out in other studies, visiting a zoo is not synonymous with learning about biodiversity: unguided tours and information posters are not a functional educational strategy by themselves (Balmford et al., 2004; Martin, 2012; Dove, 2016; Ouellette, 2017). This could be the reason for the non-association between zoo visiting frequency per year and knowledge about protected wildlife, a fundamental aspect of environmental education programs (Jensen, 2014). The Jardín Zoológico Payo Obispo zoo has three main mechanisms of environmental education, one is permanent (information labels in some exhibits), and two are temporary and intermittent (talks to visitors by animal caretakers and environmental education staff), since they are only offered on Sundays or at special events. There is no previous evidence of the impact on citizens of non-formal education at this institution.

In this sense, boa constrictors and small crocodiles have been commonly used in talks given by the caretakers of the reptile area on Sundays. It is possible that continuous exposure to these dynamics is the reason why the frequency of annual visits by respondents, especially among those who visit the zoo 10, 24, and 75 times per year, was associated with a perception of security in the presence of these reptiles. Similar results have been reported by other authors: Mann-Lang (2013) found that visitors of the "Dangerous Creatures Exhibit" diminished their fear of snakes after visiting the exhibition, while Rodríguez-Álvarez and Gómez-Ovalle (2013) achieved a similar result by obtaining a positive change in attitudes towards bats following a guided tour through an exhibition of "scary animals".

The greatest educational impacts have been achieved through interactive activities. Sponarski et al. (2016) propose that environmental education activities designed specifically for a target audience and under an experiential education model produce a positive change in people's attitudes, risk perception, and coexistence of people towards a species that causes fear and conflict (coyotes in Canada). Morgan and Gramann (1989) assessed the effects of wildlife education programs on attitudes and knowledge towards snakes among students in $5^{\text {th }}$ and $8^{\text {th }}$ grade in public and private schools in New York and New Jersey. They found that major changes in attitudes and knowledge of students were obtained through a combination of well-directed talks with objective information and direct contact with live animals. Other authors support these activities in environmental education dynamics achieve a greater impact on the attitudes, perceptions, and commitment to the conservation of endangered or less appreciated species (Ballantyne et al., 2009; Prokop et al., 2009; Ballantyne et al., 2011; Ballourd et al., 2012; Stanford, 2014; Liordos et al., 2018).

Finally, regarding the intention to donate money for species conservation, it was clearly biased towards charismatic species (e.g., jaguar, spider monkey, parrots, and birds); however, the intention to donate to any animal was mentioned in 24 occasions, only below jaguar and parrots (32 and 29 mentions, respectively). Our results are similar to those presented by Colléony et al. (2017) in a program at the Zoological Park in Paris, where the more charismatic species received more donations. This reinforces 
previous results regarding the importance of aesthetic perception and the sensation of safety as factors that influence the decision to support or not a species' conservation presented in this study (Gunnthorsdottir, 2001; Martín-López et al., 2007; Brambilla et al., 2013). Faced with this panorama, the environmental education promoted by different institutions that take care of wildlife or perform wildlife rehabilitation activities becomes more relevant (Souza et al., 2012; Feck \& Hamann, 2013).

\section{CONCLUSIONS}

This study shows that there is not a predominant factor, such as knowledge, attitude, safety, or sociodemographic profile, that determines whether an individual will support for the conservation of some target species, however, there are some tendencies with the exception of the jicotea turtle. Fear and negative aesthetic perceptions (whether animals were perceived as "ugly") were two important aspects that influenced the decision to not support the protection of the species. Both aspects had a moderate degree of association with the qualifier of danger and with the willingness of people to help animals when found injured, to support their conservation, or to choose how solve a problem related to any of the species in this work.

It is confirmed, as in other studies, that fear is the main negative attitude toward animals and persists as a decisive factor for people to decide against supporting the conservation of any species, especially when referring to less or not at all charismatic species like the boa, Morelet's crocodile, ferruginous pygmy-owl, and Virginia opossum. In turn, the lack of knowledge about a species plays an important role by encouraging perceptions and negative attitudes towards it, as was seen in the case of white-nosed coati, parrots, and cardinals. It was also related with actions towards animals, particularly in the case of Geoffroy's spider monkey: respondents that do not know it acknowledged that they would not ask for help in case of finding one injured. Finally, and more worryingly, ignorance on the Virginia opossum was negatively associated with a lack of support for its conservation.

In this sense, environmental education in institutions that host wildlife in human care must be strengthened, so that they can sensitize towards uncharismatic / "ugly" species, desensitize towards species that cause fear, and increase the knowledge of its visitors about wildlife. Non-formal environmental education in zoos acquires a fundamental role as they are, at least for the nine target species in this work, one of the main places where people meet wildlife. No statistically significant association was found between the knowledge on protected species and the frequency of respondent's visits to the zoo, which creates uncertainty about the effectiveness of the environmental education activities carried out in this zoo. However, there are associations that might indicate that attending a zoo might improve some perceptions, attitudes, and support for the conservation of some species.

At this point, we consider that "hands on" activities accompanied by a well-designed and carefully considered conservation message, as well as the incorporation of activities under an experiential education model, could potentiate educational impacts in non-formal environmental education spaces such as zoos.

ACKNOWLEDGMENTS. We thank all survey respondents for their time and cooperation and the Jardín Zoológico Payo Obispo staff for their support. We also thank the comments of two anonymous reviewers who contributed to improve this manuscript. The senior author thanks the support of Consejo Nacional de Ciencia y Tecnología (CONACYT) through the scholarship granted (CVU 840855), and El Colegio de la Frontera Sur (ECOSUR) for their facilities. 


\section{LITERATURE CITED}

Adolphs, R. (2013) The Biology of Fear. Current Biology, 23 (2), R79-R93. https://doi.org/10.1016/j.cub.2012.11.055

Ajzen, A., Fishbein, M. (1980) Understanding Attitudes and Predicting Social Behavior. Prentic Hall, Inc, Englewood Cliffs, New York, USA, 396 pp.

Almeida, L. L., García, J. S. (2009) Hacia una propuesta de educación ambiental en la comunidad de la Magdalena Atlitic, Distrito Federal. Pp: 203-224. In: A. Castillo, E. González-Gaudiano (Coords.). Educación ambiental y manejo de ecosistemas en México. Instituto Nacional de EcologíaSEMARNAT, UNAM, México.

Arnau, L., Montané, J. (2010) Aportaciones sobre la relación conceptual entre actitud y competencia, desde la teoría del cambio de actitudes. Electronic Journal of Research in Educational Psychology, 8 (3), 1283-1302.

Ballantyne, R., Packer, J., Hughes, K. (2009) Tourists' support for conservation messages and sustainable management practices in wildlife tourism experiences. Tourism Management, 30, 658-664. https://doi.org/10.1016/j.tourman.2008.11.003

Ballantyne, R., Packer, J., Sutherland, L. A. (2011) Visitors' memories of wildlife tourism: Implications for the design of powerful interpretive experiences. Tourism Management, 32, 770-779. https://doi.org/10.1016/j.tourman.2010.06.012

Ballouard, J., Provost, G., Barre, D., Bonnet, X. (2012) Influence of a field trip on the attitude of schoolchildren toward unpopular organisms: an experience with snakes. Journal of Herpetology, 46 (3), 423-428. https://doi.org/10.1670/11-118

Balmford, A., Leader-Williams, N., Mace, G. M., Manica, A., Walter, O., West, C., Zimmermann, A. (2004) Message received? Quantifying the impact of informal conservation education on adults visiting UK zoos. Catalysts for conservation: a direction for zoos in the 21 st Century, London, UK, 19-20 February, 120-136.

Bjerke, T., Reitan, O., Kellert, S. R. (1998) Attitudes toward wolves in southeastern Norway. Society and Natural Resources, 11 (2), 169-178. https://doi.org/10.1080/08941929809381070

Bjerke, T., Kaltenborn, B. P., Thrane, C. (2001) Sociodemographic correlates of fear-related attitudes toward the wolf (Canis lupus lupus). Fauna Norvegica, 21, 25-33.

Bjerke, T., Østdahl, T. (2004) Animal-related attitudes and activities in an urban population. Anthrozoös, 17 (2), 109-129. https://doi.org/10.2752/089279304786991783

Brambilla, M., Gustin, M., Celada, C. (2013) Species appeal predicts conservation status. Biological Conservation, 160, 209-2013. https://doi.org/10.1016/j.biocon.2013.02.006

Buenrostro-Silva, A., Rodríguez de la Torre, M., García-Grajales, J. (2016) Uso y conocimiento tradicional de la fauna silvestre por habitantes del Parque Nacional Lagunas de Chacahua, Oaxaca, México. Quehacer Científico en Chiapas, 11, 84-94.

Cain, L., Meritt, D. (2007). The demand for zoos and aquariums. Tourism Review International, 11 (3), 295-306. https://doi.org/10.3727/154427207783948856

Caraveo-Anduaga, J. J., Colmenares, E. (2000) Prevalencia de los trastornos de ansiedad fóbica en la población adulta de la ciudad de México. Salud Mental, 23 (5), 10-19.

Castillo, A., Bullen-Aguiar, A. A., Peña-Mondragón, J. L., Gutiérrez-Serrano, N. G. (2020) The social component of social-ecological research: moving from the periphery to the center. Ecology and Society, 25 (1), 6.

https://doi.org/10.5751/ES-11345-250106 
Chablé-Santos, J., Delfín-González, J. (2010) Uso tradicional de la fauna silvestre. Pp: 377-381. In: R. Durán-García, M. E. Méndez-González (Eds.). Biodiversidad y desarrollo humano en Yucatán. Centro de Investigaciones Científicas de Yucatán, PPD-FMAM, CONABIO, SEDUMA, México.

Colléony, A., Clayton, S., Couvet, D., Jalme, M. S., Prévot, A. (2017) Human preferences for species conservation: Animal charisma trumps endangered status. Biological Conservation, 206, 263-269. https://doi.org/10.1016/j.biocon.2016.11.035

Daniel, W. W. (1982) Estadística con aplicaciones a las ciencias sociales y a la educación. McGraw-Hill, México, 504 pp.

DeGregoria, L., Luebke, J. F., Clayton, S., Saunders, C. D., Matiasek, J., Grajal, A. (2014) Climate Change Attitudes of Zoo and Aquarium Visitors: Implications for Climate Literacy Education. Journal of Geoscience Education, 62, 502-510. https://doi.org/10.5408/13-078.1

DOF (Diario Oficial de la Federación) (2000) Ley General de Vida Silvestre. Distrito Federal, 3 de julio de 2000, vol. 6., México.

Dove, T. (2016) Investigating factors which affect visitor understanding of the information displayed on species signs: a multi-method evaluation approach. IZE Journal, 52, 39-42.

Drews, C. (2001) Wild animals and other pets kept in Costa Rican households: incidence, species and numbers. Society \& Animals, 9 (2), 107-126.

Drury, R., Homewood, K., Randall, S. (2011) Less is more: the potential of qualitative approaches in conservation research. Animal Conservation, 14 (1), 18-24. https://doi.org/10.1111/j.1469-1795.2010.00375.x

Duarte-Quiroga, A., Estrada, A. (2003) Primates as pets in Mexico City: an assessment of the species involved, source of origin, and general aspects of treatment. American Journal of Primatology, 61, 53-60. https://doi.org/10.1002/ajp.10108

Escalante-Gómez, E., Repetto, A. M., Mattinello, G. (2012) Exploración y análisis de la actitud hacia la estadística en alumnos de psicología. LIBERABIT, 18 (1), 15-26.

Feck, A. D., Hamman, M. (2013) Effect of sea turtle rehabilitation centers in Queensland, Australia, on people's perceptions of conservation. Endangered Species Research, 20, 153-165. https://doi.org/10.3354/esr00482

González, A., Moncada, J. A., Aranguren, J. (2011) Actitudes y comportamientos hacia la fauna silvestre de los visitantes del parque Bararida, Barquisimeto, Venezuela. Investigación y Postgrado, 26 (1), $227-248$.

González-Bocanegra, K., Romero-Berny, E. I., Escobar-Ocampo, M. C., García-Del Valle, Y. (2011) Aprovechamiento de fauna silvestre por comunidades rurales en los humedales de Catazajá- La libertad, Chiapas, México. Ra Ximhai, 7 (2), 219-230.

González-Martínez, M. T. (1990) Los miedos en el niño: Aspectos teóricos y un estudio directo. Revista de Pedagogía de la Universidad de Salamanca, 3, 29-44.

Gordillo-León, F., Mestas-Hernández, L., Arana-Martínez, J. M., Salvador-Cruz, J. (2015) El miedo como constructo de análisis sistemático. Alternativas en Psicología, 2, $27-47$.

Gullone, E. (2000) The development of normal fear: a century of research. Clinical Psychology Review, 20 (4), 429-451. https://doi.org/10.1016/S0272-7358(99)00034-3

Gullone, E., King, N. J. (1992) Psychometric Evaluation of a Revised Fear Survey Schedule for Children and Adolescents. Journal of Child Psychology \& Psychiatry \& Allied Disciplines, 33 (6), 987-998. https://doi.org/10.1111/j.1469-7610.1992.tb00920.x

Gunnthorsdottir, A. (2001) Physical attractiveness of an animal species as a decision factor for its preservation. Anthrozoös, 14 (4), 204-215. https://doi.org/10.2752/089279301786999355

Jensen, R. (2014) Evaluating children's conservation biology learning at the zoo. Conservation Biology, 28 (4), 1004-1011. 
https://doi.org/10.1111/cobi.12263

Kellert, S. (1985) Social and perceptual factors in endangered species management. Journal of Wildlife Management, 49 (2), 528-536. https://doi.org/10.2307/3801568

Knight, A. J. (2008) "Bats, snakes and spiders, Oh my!" How aesthetic and negativistic attitudes and other concepts predict support for species protection. Journal of Environmental Psychology, 28, 94-103. https://doi.org/10.1016/j.jenvp.2007.10.001

Kuussaari, M., Bommarco, R., Heikkinen, R. K., Helm, A., Krauss, J., Lindborg, R., Öckinger, E., Pärtel, M., Pino, J., Rodà, F., Stefanescu, C., Teder, T., Zobel, M., Steffan-Dewenter, I. (2009) Extinction debt: a challenge for biodiversity conservation. Trends in Ecology and Evolution, 24, 564-571. https://doi.org/10.1016/j.tree.2009.04.011

Lindemann-Matthies, P., Kamer, T. (2006) The Influence of an interactive educational approach on visitors' learning in a Swiss Zoo. Science Education, 90, 296-315. https://doi.org/10.1002/sce.20127

Liordos, V., Kontsiotis, V. J., Anastasiadou, M., Karavasias, E. (2017) Effects of attitudes and demography on public support for endangered species conservation. Science of the Total Environment, 595, 25-34. https://doi.org/10.1016/j.scitotenv.2017.03.241

Liordos, V., Kontsiotis, V. J., Kokoris, S., Pimenidou, M. (2018) The two faces of Janus, or the dual mode of public attitudes towards snakes. Science of the Total Environment, 621, 670-678. https://doi.org/10.1016/j.scitotenv.2017.11.311

Luna-Plascencia, R., Castañón-Barrientos, A., Raz-Guzmán, A. (2011) La biodiversidad en México: su conservación y las colecciones biológicas. Ciencias, 101, 36-43.

Mann-Lang, J. (2013) Snakes are scary - or are they? A preliminary evaluation of the dangerous creatures reptile exhibit at uShaka Sea World, Durban, South Africa. IZE Journal, 50, 19-21.

Martin, R. (2012) A study of public education in zoos with emphasis on exhibit labels. IZE Journal, 48, $55-59$.

Martín-López, B., Montes, C., Benayas, J. (2007) The non-economic motives behind the willingness to pay for biodiversity conservation. Biological Conservation, 139, 67-82. https://doi.org/10.1016/j.biocon.2007.06.005

Méndez-Cabrera, F., Montiel, S. (2007) Diagnóstico preliminar de la fauna y flora silvestre utilizada por la población maya de dos comunidades costeras de Campeche, México. Universidad y Ciencia, 23 (2), 127-139.

Meyer, D., Zeileis, A., Hornik, K. (2020). vcd: Visualizing Categorical Data. R package version 1, 4-7.

Morgan, J. M., Gramann, J. H. (1989) Predicting effectiveness of wildlife education programs: a study of students' attitudes and knowledge toward snakes. Wildlife Society Bulletin, 17, 501-509.

Moss, A., Esson, M. (2013) The educational claims of zoos: where do we go from here? Zoo Biology, 32, $13-18$. https://doi.org/10.1002/zoo.21025

Moss, A., Jensen, E., Gusset, M. (2017) Impact of a global biodiversity education campaign on zoo and aquarium visitors. Frontiers in Ecology and the Environment, 15 (5), 243-247. https://doi.org/10.1002/fee.1493

Öhman, A., Mineka, S. (2001) Fears, phobias, and preparedness: toward and evolved module of fear and fear learning. Psychological Review, 108 (3), 483-522. https://doi.org/10.1037/0033-295x.108.3.483

Ouellette, B. (2017) How zoo signs can increase the quality of guest education. IZE Journal, 53, 12-14.

Prokop, P., Özelb, M., Uşak, M. (2009) Cross-cultural comparison of student attitudes toward snakes. Society and Animals, 17, 224-240. https://doi.org/10.1163/156853009X445398 
Puc-Gil, R. A., Retana-Guiascón, O. G. (2012) Uso de la fauna silvestre en la comunidad maya Villa de Guadalupe, Campeche, México. Etnobiología, 10 (2), 1-11.

Quijano-Hernández, E., Calmé, S. (2002) Patrones de cacería y conservación de la fauna silvestre en una comunidad maya de Quintana Roo, México. Etnobiología, 2 (1), 1-18.

R Core Team (2018) R: A language and environment for statistical computing. R Foundation for Statistical Computing, Vienna, Austria. Available: https://www.R-project.org/

Ramírez-Mella, M., Candelaria-Martínez, B., Dorantes-Jiménez, J., Tarango-Arámbula, L.A., FlotaBañuelos, C. (2016) Uso y aprovechamiento de fauna silvestre en zonas rurales de Campeche, México. Agroproductividad, 9 (9), 3-9.

Rodríguez-Álvarez, C., Gómez-Ovalle, P. (2013) 'Fear' as an educative tool. IZE Journal, 49, 41-42.

Røskaft, E., Händel, B., Bjerke, T., Kaltenborn, B. P. (2007) Human attitudes towards large carnivores in Norway. Wildlife Biology, 13 (2), 172-185. https://doi.org/10.2981/0909-6396(2007)13[172:HATLCI]2.0.CO;2

Scherer, M. W., Nakamura, C. Y. (1968) A fear survey schedule for children (FSS-FC): a factor analytic comparison with manifest anxiety (CMAS). Behaviour Research \& Therapy, 6 (2), 173-182. https://doi.org/10.1016/0005-7967(68)90004-1

Schlegel, J., Rupf, R. (2010) Attitudes towards potential animal flagship species in nature conservation: A survey among students of different educational institutions. Journal for Nature Conservation, 18 (4), 278-290. https://doi.org/10.1016/j.jnc.2009.12.002

Secretaría de Economía (2014) Norma Mexicana NMX-AA-165-SCFI-2014 que establece los requisitos para la certificación con respecto al bienestar animal, conservación, investigación, educación y seguridad en los zoológicos. Available: http://biblioteca.semarnat.gob.mx/janium/Documentos/Ciga/agenda/DOFsr/DO3424.pdf (last access May 19 2020).

Segovia-Castillo, A., Chablé-Santos, J., Delfín-González, H., Sosa-Escalante, J., HernándezBetancourt, S. F. (2010) Aprovechamiento de la fauna silvestre por comunidades mayas. Pp: 385387. In: R. Durán-García, M. E. Méndez-González (Eds.). Biodiversidad y desarrollo humano en Yucatán. Centro de Investigaciones Científicas de Yucatán, PPD-FMAM, CONABIO, SEDUMA.

Souza, C. S. A., Teixeira, C. P., Young, R. J. (2012) The welfare of an unwanted guest in an urban environment: the case of the white-eared opossum (Didelphis albiventris). Animal Welfare, 21, 177183. https://doi.org/10.7120/09627286.21.2.177

Sponarski, C. C., Vaske, J. J., Bath, A. J., Loeffler, T. A. (2016) Changing attitudes and emotions toward coyotes with experiential education. The Journal of Environmental Education, 47, 296-306. https://doi.org/10.1080/00958964.2016.1158142

Stanford, A. (2014) Can I touch it?: Zoo program impacts. IZE Journal, 50, 64-67.

Swanagan, J. S. (2000) Factors influencing zoo visitors' conservation attitudes and behavior. The Journal of Environmental Education, 31 (4), 26-31. https://doi.org/10.1080/00958960009598648

Taylor, S. (1998) The hierarchic structure of fears. Behaviour Research and Therapy, 36, 205-214. https://doi.org/10.1016/S0005-7967(98)00012-6

Valdez-Medina, J. L., López-Romero, I., Torres-Aristeo, O., Piña-Monroy, M., González-Arratia, N. I., López-Fuentes, A., Maya-Martínez, M. U. (2010) Los tipos de miedo prevalentes por generación y por sexo. Revista Electrónica de Psicología Iztacala, 13 (4), 163-181.

WWF/Dalberg (2012) Fighting illicit wildlife trafficking: A consultation with governments. WWF International, Gland, Switzerland. 